\title{
AOR
}

Selected Papers of \#AolR2021:

The 22nd Annual Conference of the

Association of Internet Researchers

Virtual Event / 13-16 Oct 2021

\section{IS OTT IN INDIA 'OVER-THE-TOP’? RE-PRESENTATION, REGULATION AND RELIGIOUS SENTIMENTS IN INDIAN OTT}

Anmol Dutta

English and Writing Studies, University of Western Ontario

\section{OTT in India}

The recent OTT (over-the-top) regulation measures in India brings Netflix India and Amazon Prime Video, among other subscription based video platforms under the ambit of the Ministry of Information and Broadcasting. On November 11, 2020, the Indian government declared that all OTT streaming platforms, including Netflix and Amazon Prime Video, would be forced to undergo government regulation. As per the government regulations announced on February 25, 2021, the rules "borrow heavily from the existing regulations and structure governing the television media, including content codes and grievance redressal structure" (A.N. Dutta). At the outset, I want to acknowledge that in order to maintain the integrity of the content being disseminated, and to ensure its appropriate reception, regulation is not the problem-the problem arises when one notices that there is a pattern to this regulation; in this case, aligning towards the right-wing interests in the country.

Cultural policing turned into regulation is not an occurrence in vacuum, rather, it shapes the truths that negotiate 'protecting' cultural sensibilities in 2020s' India. While other Indian OTT players like Voot, Disney + Hostar, MX player, Alt Balaji, Zee Plus, etc. cater specifically to the local audience, Amazon Prime and Netflix, being two primary international OTT giants, relay an India that is accessible to the global audience. These platforms, hence, re-present Indian realities, becoming national projects in their own right. Mediating national(ist) negotiations of cultural heritage in a global space, Netflix India and Amazon Prime Video (re)fashion the "national imaginary", inherently becoming a "project of nationhood" (qtd. in Clini 247). As the virtual becomes our reality, digital platforms enable the vision of a fluid world, that widens "the range of our imaginary geography" (qtd. in Lobato 9). The popular notion of art transcending borders compels us to question if Netflix and Prime Video "[are] global service[s] with local versions, or a collection of national services tied together into a global platform?" (Lobato and Lotz 135).

Suggested Citation (APA): Dutta, A. (2021, October). Is OTT in India 'Over-The-Top'? Re-Presentation, Regulation and Religious Sentiments in Indian OTT. Paper presented at AolR 2021: The 22nd Annual Conference of the Association of Internet Researchers. Virtual Event: AolR. Retrieved from http://spir.aoir.org. 


\section{Regulation or Cultural Policing?}

Before the regulations came to fruition in the country, several shows on Netflix India and Prime Video were brought under fire for "hurting religious sentiments" (an equivalent to specifically being anti-Hindu). A few weeks after the release of the adaptation of Vikram Seth's A Suitable Boy on Netflix India in November 2020, furore erupted as a result of an on-screen kiss shared between a Hindu girl, Lata and a Muslim boy, Kabir against the backdrop of a temple-calling for a ban on the OTT platform as \#BanNetflixIndia trended on Twitter. In January 2021, the Amazon Prime political thriller, Tandav, came under scrutiny for being "anti-Hindu" over a scene that 'wrongfully depicts' the Hindu deity, Lord Shiva, leading to a host of FIRs and the scene being eventually edited out of the series. While these forms of regulation have been framed as "guidance", they are grounded within religious fundamentalist policing that threatens the fabric of democracy and freedom of expression in the nation (Dutta forthcoming).

The resistance towards Netflix India, specifically, started with the Netflix India's first Indian original series Sacred Games (2018); and continued with shows like Ghoul (2018), Leila (2019), and finally to A Suitable Boy (2020), as these shows allegedly "paint an incorrect picture of Hindus and India globally" (Financial Express). The complaint by a right-wing Hindu group activist lodged against the platform became national news which read: "Almost, every series on Netflix India is with the intention to defame the country on a global level. It is with deep rooted Hinduphobia that the platform is portraying the nation in a bad light" (Financial Express).Digital entertainment in India has been at the forefront of cultural warfare in the midst of a global pandemic, reeling under a form of policing that 'safeguards' Indian sensibilities, leading to a slippage between Hindu sentiments and right-wing religious politics. This regulation, I argue, has replayed panoptic cultural policing in the current political climate in the country by weaponizing religious sentiments to propel right-wing fundamentalism.

\section{Conclusion}

The definition of "screens" is evolving, as the pandemic has people hooked to their screens more than ever, making the need to police content viewed on these platforms seemingly urgent. At a time of global fragility and home quarantine, it became more important than ever to exert control over what can be seen, or rather, what should not be seen-akin to the notion that a problem is not a 'problem', until the masses see it. Manipulating "the terms of appearance", these images accused of hurting religious sentiments are 'framed' to unwittingly reveal themselves (Butler 11), causing a dent in the post-colonial perception of India being a "country where diverse faiths, languages, and cultures co-exist peacefully within the boundaries of a single peacefully within the boundaries of a single state" (Khilnani 151). Through Judith Butler's narrative of "framing images", I argue that content on these platforms is anchored in an external locus, posing a threat of not making the country look good. In a seemingly (in)dependent internet age, where the virtual is our reality, I explore what it means to submit to or to resist this new reality in 2020s' India. 


\section{References}

"BanNetflixInIndia trends on Twitter after Shiv Sena member's complaint over platform's 'deep-rooted Hinduphobia'." Financial Express, September 2019, https://www.financialexpress.com/india-news/ban-netflix-in-india-trends-after-shiv-senamember-files-complaint-against-online-streaming-giant-for-disrespectinghindus/1698139/

Butler, Judith. Frames of War: When is Life Grievable?, Verso, 2009. pp. 11-12.

Clini, Clelia. "From Bollywood to 'Hindependent' Film: Narrating the Indian Diaspora." Beyond Borers and Boundaries, edited by Nilufer Bharucha et. al, NavVishnu Publications, 2018, pp. 247.

Dutta, Amrita Nayak. "This is how Modi govt's new rules will regulate digital media and OTT content." The Print, February 25, 2020, https://theprint.in/india/this-is-how-modigovts-new-rules-will-regulate-digital-media-and-ott-content/611909/.

Dutta, Anmol. "Content Carnival: (Re)viewing Representation, Religion and OTT Culture in India." Streaming and Screen Cultures Asia-Pacific, edited by Michael Samuel and Louisa Mitchell, Palgrave Macmillan, forthcoming 2022.

Khilnani, Sunil. The Idea of India, Penguin Books, 1997, pp. 151-152.

Lobato, Roman and Amanda D. Lotz. "Imagining Global Video: 'The Challenge of Netflix' in 'In Focus: Global Netflix'." Journal of Cinema and Media Studies, vol. 59, no. 3, University of Texas Press, 2020, pp. 135.

Lobato, Ramon. "Preface." Netflix Nations: The Geography of Digital Distribution, New York University Press, 2019, pp. 9. 